\title{
Assessing components of the natural environment of the Upper Danube and Upper Brahmaputra river basins
}

\author{
S. Lang ${ }^{1}$, A. Kääb ${ }^{2}$, J. Pechstädt ${ }^{3}$, W.-A. Flügel ${ }^{3}$, P. Zeil ${ }^{1}$, E. Lanz ${ }^{4}$, D. Kahuda ${ }^{5}$, R. Frauenfelder ${ }^{2}$, \\ K. Casey $^{2}$, P. Füreder ${ }^{1}$, I. Sossna ${ }^{3}$, I. Wagner $^{4}$, G. Janauer ${ }^{4}$, N. Exler ${ }^{4}$, Z. Boukalova ${ }^{5}$, R. Tapa ${ }^{6}$, J. Lui ${ }^{7}$, \\ and N. Sharma ${ }^{8}$ \\ ${ }^{1}$ Centre for Geoinformatics, University of Salzburg, Salzburg, Austria \\ ${ }^{2}$ Department of Geosciences, University of Oslo, Oslo, Norway \\ ${ }^{3}$ Department of Geoinformatics, University of Jena, Jena, Germany \\ ${ }^{4}$ Department of Limnology, University of Vienna, Vienna, Austria \\ ${ }^{5}$ VODNI ZDROJE, a.s., Prague, Czech Republic \\ ${ }^{6}$ ICIMOD, Kathmandu, Nepal \\ ${ }^{7}$ Institute for Tibetan Plateau Research, Lhasa, China \\ ${ }^{8}$ Indian Institute of Technology, Roorkee, India
}

\begin{abstract}
A comprehensive understanding of the interplay between the natural environment and the human dimension is one of the prerequisites to successful and sustaining IWRM practises in large river basins such as the Upper Brahmaputra river basin or the Upper Danube river basin. These interactions, their dynamics and changes, and the likely future scenarios were investigated in the BRAHMATWINN project with a series of tools from remote sensing and geoinformatics. An integrated assessment of main components of the natural environment in the two river basins as well as in five reference catchments within those basins, has led to the delineation of hydrological response units (HRUs). HRUs are spatial units bearing a uniform behaviour in terms of the hydrological response regime, as a function of physical parameters land use, soil type, water, vegetation cover and climate. Besides the delineated HRUs which are available in a spatially exhaustive manner for all reference catchments, the following information were provided as spatial layers: (1) uniform digital surface models of both the twinned basins and the reference catchments; (2) glacier areas and the magnitude of glacier loss; (3) mountain permafrost distribution and identification of areas particularly affected by permafrost thaw; (4) a consistent land use/land cover information in all reference catchments; and (5) the vulnerabilities of wetlands and groundwater in terms of anthropogenic impact and climate change.
\end{abstract}

\section{Introduction and objectives}

Sustainable integrated water resources management (IWRM) aims to distribute water both in sufficient quantity and quality based on detailed knowledge of the regeneration potential inherent in the hydrological regime of the river basin, and balance this potential against projected demands. BRAHMATWINN addressed this notion by a comprehensive assessment of the interactive dynamics between the natural environment (NE) and its human dimension (HD). Each basin, country or region has its specific natural environment and human dimension, a history of water use, cultures and customs, different stages and priorities of economic development -

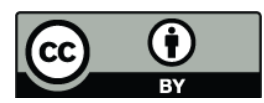

Correspondence to: S. Lang

(stefan.lang@sbg.ac.at) which in all renders various value judgements for water use and distribution.

The results presented in this chapter have been generated in a respective work package (WP) \#3 of the BRAHAMTWINN project. The objective of this WP was to provide comprehensive assessment and analysis of the natural environment comprising groundwater, glaciers, permafrost, terrain, land use, land cover, and eco-hydrological research to derive the interactive dynamics of the system's components. In particular the following research objectives have been pursued:

\section{Terrain classification and relief characteristics:} A priority data layer for assessing water resources dynamics is the morphology of the surface. Two different representations are generally used: Digital Surface Models (DSM) - the height above sea-level including 
all features on the surface (e.g. trees, houses, etc.), and the Digital Terrain Models (DTM), the height a.s.l. truly to the surface. Height measurements from space or airborne platforms naturally render DSMs which can be converted to DTMs by correcting for land-cover. For the scales and applications of BRAHMATWINN the difference between the two models was considered negligible.

\section{Glacier cover and permafrost distribution:}

In cold regions such as in alpine mountain areas, glacier cover, permafrost distribution and their changes over time can have significant influence on the water cycle and natural disasters. These effects often include downstream areas outside of the direct glacial and periglacial zone. The first rationale of this study was thus to compile the past and present glacier distribution in the Upper Brahmaputra River basin (UBRB) and the Upper Danube River Basin (UDRB) for suitable points in time in order to detect and analyse recent changes in glacier cover in the basins. The second rationale was to model the mountain permafrost distribution in the UBRB and the UDRB, and to validate the model results in particular for the UBRB where such model was developed for the first time. Both results were analysed to better understand the glacial and periglacial character of the two basins, and assess potential climate change impacts related to glaciers and permafrost.

\section{Land use and land cover:}

Land use and land cover information is a crucial basis for natural resources management, environmental variables, global and regional change affecting ecological processes. Despite the significance of land cover as an ecological variable, our understanding of land cover dynamic is poor. For the common land cover and land use classification, the LULC group of BRAHMATWINN has developed an adaptive and harmonized classification scheme. During an expert meeting this scheme has been tested by jointly applying the scheme to the different reference areas selected in the twinning basins. Land use and Land Cover (LULC) should adhere to the scheme proposed by the IPCC, but adapted to the specific requirements and settings imposed by the BRAHMATWINN twinning approach.

\section{Groundwater vulnerability:}

To provide hydrogeological background for "what if" scenarios, there was a detailed study on aquifer vulnerability. Mainly because of shallow exploited aquifers and a very high precipitation the aquifer vulnerability in most of the area can be concerned as significantly high. The groundwater availability based on comparison of groundwater recharge and groundwater draft show positive values all over the region.

\section{Eco-hydrology and wetland characteristics:}

Both twinning basins have extensive wetland areas in the alpine mountain headwaters as well as in flood plains along its course. Most of them are unique in their biodiversity and at the same time strongly dependant on the hydrological dynamics of the river system. Climate change will influence the ecosystem services of these wetlands and eco-hydrological strategies can help to develop measures which allow rehabilitation and protection of these landscape features. Their functions in terms of flood retention, purification of flood water (sinks for sediments and nutrients, etc.) and groundwater recharge have been assessed.

\section{Role within the integrated project}

The assessment and analysis of the natural environment is a prerequisite to design adaptive IWRM options that account for the natural water resource potential and its sustainable regeneration dynamics. This has been addressed by the following two main scientific and technological objectives:

1. Assess, classify and quantify the components of the natural environment such as topography, climate, hydrology, snow and glacier cover, permafrost and slope stability, land use and land cover, soils and geology, sediments and erosion, water quality, groundwater, ecohydrology, and biodiversity. Those are required inputs to all subsequent workpackages as well as relevant to the assessment of present IWRM practices and the development and evaluation of adaptive IWRM options in WP \#10. The assessment provides the parameter quantification used for the hydrological modelling in WP \#7.

2. Based on the spatial representation of the natural environment, a regionalisation of the basins heterogeneity by means of Hydrological Response Units (HRU) is carried out. HRUs are considered the baseline information elements for the delineation of Water Resources Response Units (WRRU) applied as model entities for the development and evaluation of adaptive IWRM options in WP \#10.

The research work carried out to realize them comprised field based research, data integration, remote sensing and GIS analyses and also makes use of the established stakeholder processes in the twinning basins. It combines innovative techniques with traditional field campaigns for ground validation, and has integrated available datasets from global and national depositories.

The regionalization concept of Response Units (RU) as defined by Flügel (1995) was applied to the assessment results to delineate Hydrological Response Units (HRU) that classify the distributed heterogeneity of the natural environment in the UDRB and the UBRB. Results are collected and 
presented in a comprehensive digital GIS map assembly populated into the River Basin Information System (RBIS).

\section{Scientific methods applied}

\subsection{Terrain classification and relief characteristics}

For a global comparison of large areas, the only consistent data set having the specifications required by BRAHMATWINN, come from space-based platforms. Shuttle Radar Topography Mission (SRTM) delivers DSM data at a spatial resolution of $90 \times 90 \mathrm{~m}$ raster cell size. These data can be freely downloaded but need to be corrected for data voids and major errors occurring at specific land cover features (e.g. water-land boundary, mountainous areas). For compatibility reasons, a calibration of height values at reference survey points was carried out. Voids were filled by data derived by stereoscopic methods applied to optical satellite imagery from the Advanced Space-borne Thermal Emission and Reflection radiometer (ASTER), an experimental sensor on the Terra Platform.

\subsection{Glacier cover and permafrost}

Mapping of glaciers and their recent changes over time, and permafrost distribution modelling contributed to the entire integrated project by the following ways: (i) glacier areas are part of the surface cover maps essential for the project; (ii) characterization of the glacier and permafrost distribution in the according catchments and basins as an indicator for their natural sensitivity to climatic changes and for the potential related impacts.

The 1970s glacier inventory compiled for the UBRB was mainly based on the Chinese Glacier Inventory. For the Wang Chu catchment in Bhutan, the inventory was digitized from Corona satellite data from 1974. The year 2000 glacier inventories in the UBRB were mainly compiled from Landsat 7 Enhanced Thematic Mapper (ETM+) multispectral satellite data. For the UDBR, the pre-existing glacier inventories were digitized from aerial photos of 1969 and 1998 (Lambrecht and Kuhn, 2007).

The Chinese Glacier Inventory was carefully checked glacier by glacier and erroneous glaciers were excluded from the multi-temporal analyses. In the catchment of the Lhasa River (Tibet) and the Wang Chu (Bhutan), and the additional test region the north-western UBRB, the glacier outlines for around the year 2000 were obtained by semi-automatic segmentation (Kääb et al., 2002; Paul et al., 2002; Frauenfelder and Kääb, 2009). The results (glacier area and area changes) were also up-scaled to the entire UBRB using the two river basins and the north-western test area. The glacier volumes in the test areas were estimated using two widely used empirical area-volume relations.

The permafrost distribution in the UDRB was modelled as a function of the mean annual air temperature as derived from the elevation of the $-2^{\circ}$ isoline, the mean temperature lapse rate in the area of concern, and the potential incoming short-wave radiation (Hoelzle, 1996). Both factors, elevation and radiation, were derived using the SRTM elevation model. The model results of the UBRB were validated using a physically based permafrost model in a small validation area, alongside with a rock glacier inventory that was compiled from high-resolution satellite data. For the UDRB, a model similar to the above was applied, but instead of using a radiation term, an aspect-dependent probability threshold was applied.

\subsection{Land use and land cover (LULC)}

Landsat-TM datasets with complete coverage available from the year 2000 ( $\pm 1 \mathrm{yr}$ ) together with complement satellite images and already published data available from the Web were used to produce a homogeneous LULC classification for all test catchments. For compatibility reasons the classification was carried out according to the IPCC (2003) guideline which uses six LULC classes.

To ascertain comparative studies between the twinning UDRB and UBRB, a harmonized classification scheme was developed by the LULC working group. The classification scheme is adaptive and hierarchical, where different levels are defined by the underlying data type, the availability of external knowledge and ground truthing.

\subsection{Groundwater vulnerability}

This study is contributing to the description of natural conditions and the determination of "what if" scenarios from the groundwater point of view. The methodology was chosen to be coherent with available datasets and to be reasonably demanding with regards to the limited data resources available and their accuracy. The assessment of aquifer vulnerability and groundwater vulnerability is also a contribution to the socio-economic investigation, where the access to potable water and its quality plays a crucial role. Regarding social and economic development there must also be water resources taken into account as well as the risks of their depletion or devaluation caused by taking impropriate decisions and actions.

Groundwater resources have been assessed in regard to availability, recharge and use. In order to study groundwater availability, one has to consider the different sources of recharge. For Assam, the river Brahmaputra and its tributaries are the main source of ground water recharge, as the flood plains in the vicinity of the rivers act as storages for groundwater. To meet the additional demand during non-monsoon periods, groundwater is withdrawn from the flood plains. Due to this practice the Brahmaputra flood plain in Assam can be considered as one with significantly high aquifer vulnerability due to the presence of very shallow aquifers all over the area, where the typical depth to 
groundwater is approximately up to $5 \mathrm{~m}$. According to an analysis using DRASTIC (see below), the highest aquifer vulnerability has been determined in the districts of Nagaon, Karbi Anglong and in lower elevated parts of Sonitpur and Lakhimpur. The highest resistance, as characterized by the lowest aquifer vulnerability, was detected in the mountain districts of Kokrajhar, Bongaigaon, Nalbari, Barpeta and in the higher parts of Karbi Anglong.

Because of the considerable lack in data concerning both geological and environmental information, it was decided to use a modified international standard assessment tool the DRASTIC model (Kabera and Zhaohui, 2008). This model named for the seven factors considered in the method: Depth to water, net Recharge, Aquifer media, Soil media, Topography, Impact of vadose zone media, and hydraulic Conductivity of the aquifer (Aller et al., 1985). The model applies an indexing method which is based on available studies from an area of east India (see also Jha and Sebastian, 2005), but unfortunately a lot of simplifications had to be done to get through data insufficiency and unreliability. Furthermore, there was also the groundwater availability of Assam assessed using available estimates of groundwater recharge and groundwater draft studies in this area.

There were too few data of contaminants in this area to be valuably assessed, although high concentrations of fluorides and arsenic locally are of big concern in potable water (Das, 2009).

The DRASTIC model is the basis for the aquifer sensitivity rating used for these maps. It examines several components that are important in determining the level of aquifer sensitivity, and which are related to the relative ease with which a contaminant applied on or near a land surface can migrate to the aquifer of interest. There is a standardized set of indicators and criteria that play a key role in groundwater recharge. To be included into groundwater vulnerability their rating values will dramatically vary comparing different localities from all over the world. The DRASTIC tool therefore provides relative rather than absolute information on the issue of aquifer vulnerability in the meaning of simplicity/difficulty for a contaminant to leak through unsaturated zone and reach the major groundwater aquifers.

\subsection{Eco-hydrology and wetland characteristics}

The spatial extent of the river-scape was delineated by wetland-polygons from pre-existing data and wetlands-, water bodies-, and water course-polygons extracted from the LULC-classification. Remote sensing techniques furthermore provided the Normalized Difference Vegetation Index (NDVI) applied for the wetland analysis. Vulnerability of the wetlands was assessed particularly with regard to (1) the pressure of the adjacent human population on wetlands and to (2) the possible effects of climate change on the wetland distribution. Threat caused by density of settlements was partly derived from population-data provided by project partners working on socio-economic aspects.

\subsection{Hydrological system analysis and delineation of Hydrological Response Units (HRU)}

The concept of Response Units (RU) and Hydrological Response Units (HRU) has been described in detail by Flügel (1995, 1997). It is based on a thorough hydrological system analysis comprising statistical analysis of the climate and runoff regime and a complement landscape analysis. The latter identifies and quantifies the interactions of processes and their controlling parameters in the atmosphere - topography - vegetation - pedosphere - lithosphere component system and will provide as ultimate result the knowledge about the distributed hydrological response to rainfall input within the river basin.

Because of their process oriented delineation criteria each HRU has a hydrological process dynamic which is homogeneous in their respective spatial domain if compared to neighbouring HRU. They are applied as spatial distributed model entities in physically based hydrological process models like PRMS (Leavesley et al., 1983) and J2000 (Krause, 2002) and represent the conceptual landscape model the Jena Environment System Analysis Toolset (JESAT) is based on (Flügel, 2009).

Based on the quantified analyses of the hydrological dynamics and the quality of the GIS input data the criteria catalogue of the HRU regionalisation concept has been adapted to the UDRB and the UBRB. HRUs were delineated in the UDRB and the UDRB by means of GIS analysis comprising knowledge based reclassification, an overlay and elimination approach. At the macro-scale of the UDRB and the UBRB twinning basins LULC obtained from MODIS and the digital elevation model (DEM) from the US-Geological Survey both with a $1 \mathrm{~km}$ resolution have been used. For the test catchments of the Salzach River (Austria) and the Lech River (Germany) in the UDRB and the Lhasa River (Tibet), the Wang Chu (Bhutan) and the floodplain of Assam enhanced HRUs based on a $90 \mathrm{~m}$ resolution DEM have been provided.

\section{Results achieved and deliverables provided}

\subsection{Terrain classification and relief characteristics}

For the river basin level (Upper Brahmaputra Basin, Upper Danube Basin) DSMs were re-sampled from $90 \mathrm{~m}$ to a $1 \mathrm{~km}$-raster, and clipped to the basins' boundaries (Fig. 1). The $90 \mathrm{~m}$ DSMs served to represent the reference catchments. For providing adequate data for modelling, sinks in the DSMs were filled where required.

The resulting DSMs have been classified according to morphometric and hydrological criteria required to delineate the HRUs as well as to model parameters such as permafrost 


\section{Map 1: Upper Brahmaputra River Basin (UBRB)}

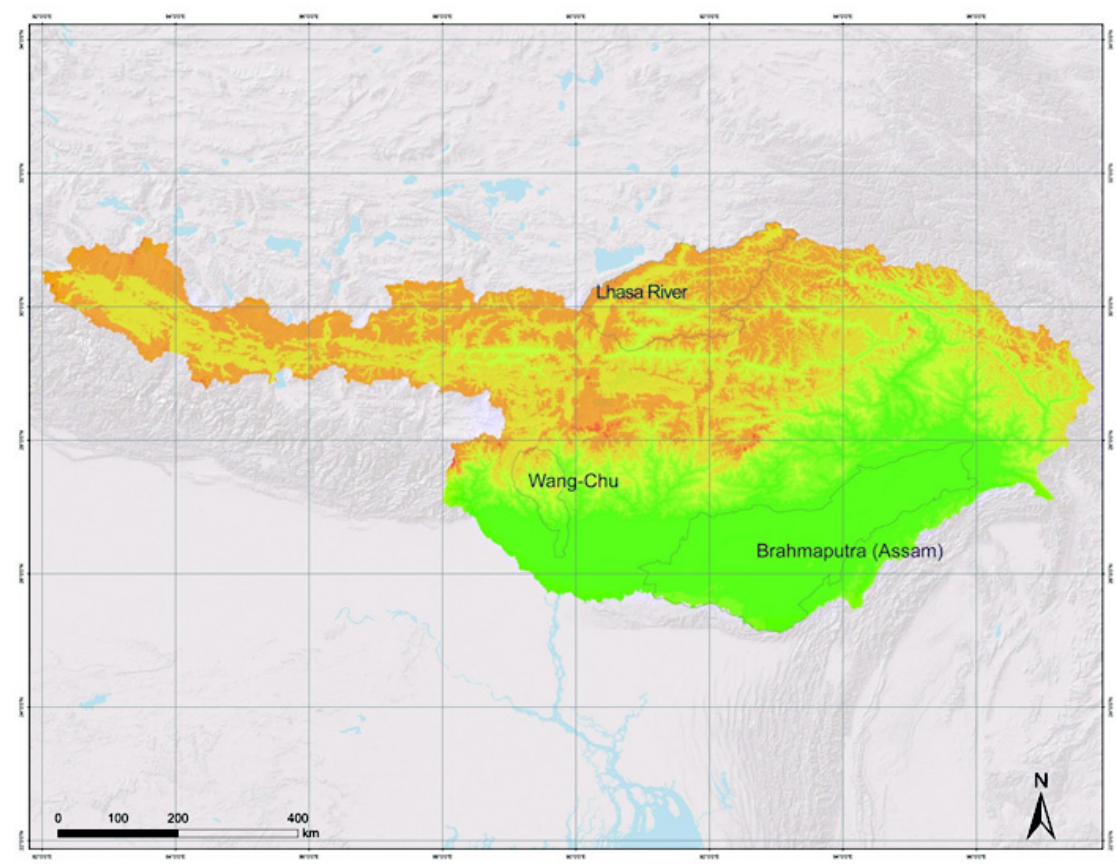

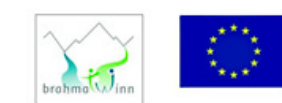
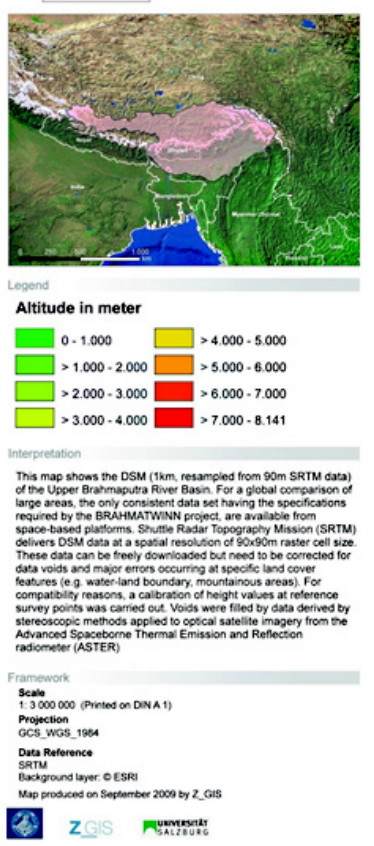

Figure 1. Digital Surface Model for the Upper Brahmaputra River Basin and reference catchments.

distribution and slope instability. Therefore the morphometric parameters aspect, slope, profile curvature, solar radiation index, flow accumulation and flow direction were derived from the DSM.

A validation of the Version 3 datasets of the SRTM has been carried out in the Bavarian Alps near Berchtesgaden, in an area with steep, nearly vertical slopes, and high altitude differences. The conclusions can be summarised as follows: (1) Previous vertical accuracy assessments of the SRTM data seem a bit too optimistic, particularly for high mountain areas. (2) Although Version 3 gives a better impression, the improvement reached is limited for the validated area (e.g. for areas where other DTM data was available). (3) A trend of underestimating heights within interpolated areas and overestimating outside them is observed. (4) Areas with interpolated surfaces (ex-voids) should not be used for terrain analysis or as test areas without checking the vertical accuracy.

\subsection{Glacier and permafrost}

Repeated glacier inventories of the Lhasa river and Wang Chu catchments have been produced (Table 1, Fig. 2). The glacier area in the Lhasa river catchment is about eight times larger than in the Wang Chu catchment. The glacier area change in both areas is similar in both catchments with around $-7 \%$ per decade, though slightly lower in the Wang $\mathrm{Chu}$, presumably due to the significant debris cover of the
Table 1. Glacier areas and area changes.

\begin{tabular}{lll}
\hline & $\begin{array}{l}\text { Lhasa river } \\
\text { catchment }\end{array}$ & $\begin{array}{l}\text { Wang Chu } \\
\text { catchment }\end{array}$ \\
\hline Catchment area & $32752 \mathrm{~km}^{2}$ & $4687 \mathrm{~km}^{2}$ \\
Glacier area $\sim 2000$ & $429 \mathrm{~km}^{2}$ & $50 \mathrm{~km}^{2}$ \\
Glacier area $\sim 1970$ & $535 \mathrm{~km}^{2}$ & $60 \mathrm{~km}^{2}$ \\
Glacier area change per decade & $-7.1 \% / 10 \mathrm{yr}$ & $-6.6 \% / 10 \mathrm{yr}$ \\
\hline
\end{tabular}

glacier tongues in the Wang Chu. Such debris cover reduces glacier ablation and thus reduces glacier mass loss and retreat.

The glacier area loss in the Salzach catchment in the period between 1970 and 2000 was similar, slightly lower, to the area loss in the UBRB catchments (Table 1). Total glacier area percentages for the catchments are low with about $1 \%$. The Lhasa river catchment is slightly more glaciered than the Wang Chu one. The glacier area percentage of the Salzach catchment is between the one of Lhasa River and Wang Chu. All three catchments lost only $0.1 \%$ in total glacier area percentage between the 1970s and ca. 2000. The total glacier area percentage for both UBRB catchments is about half of that for the entire UBRB. Glacier changes in the UBRB will thus have potentially slightly more impact than in the two UBRB test catchments investigated in detail. 
Map 3: Detailed map of modelled permafrost distribution and glacier cover 1970 and 2000 in the Lhasa river catchment
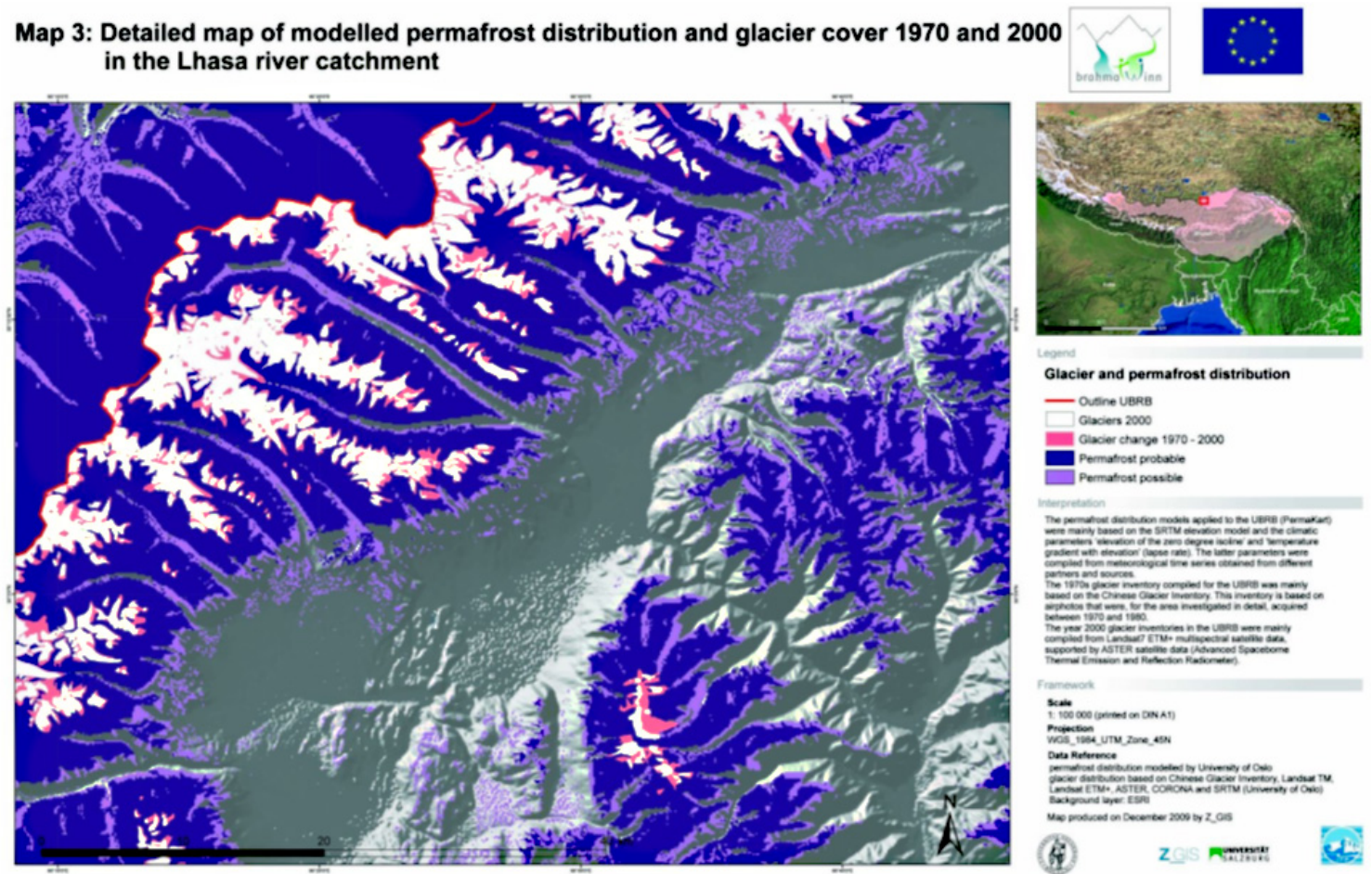

Figure 2. Glacier change and permafrost distribution for a reference site in the Lhasa catchment.

Map 1: Modelled permafrost distribution and glacier cover in the UBRB
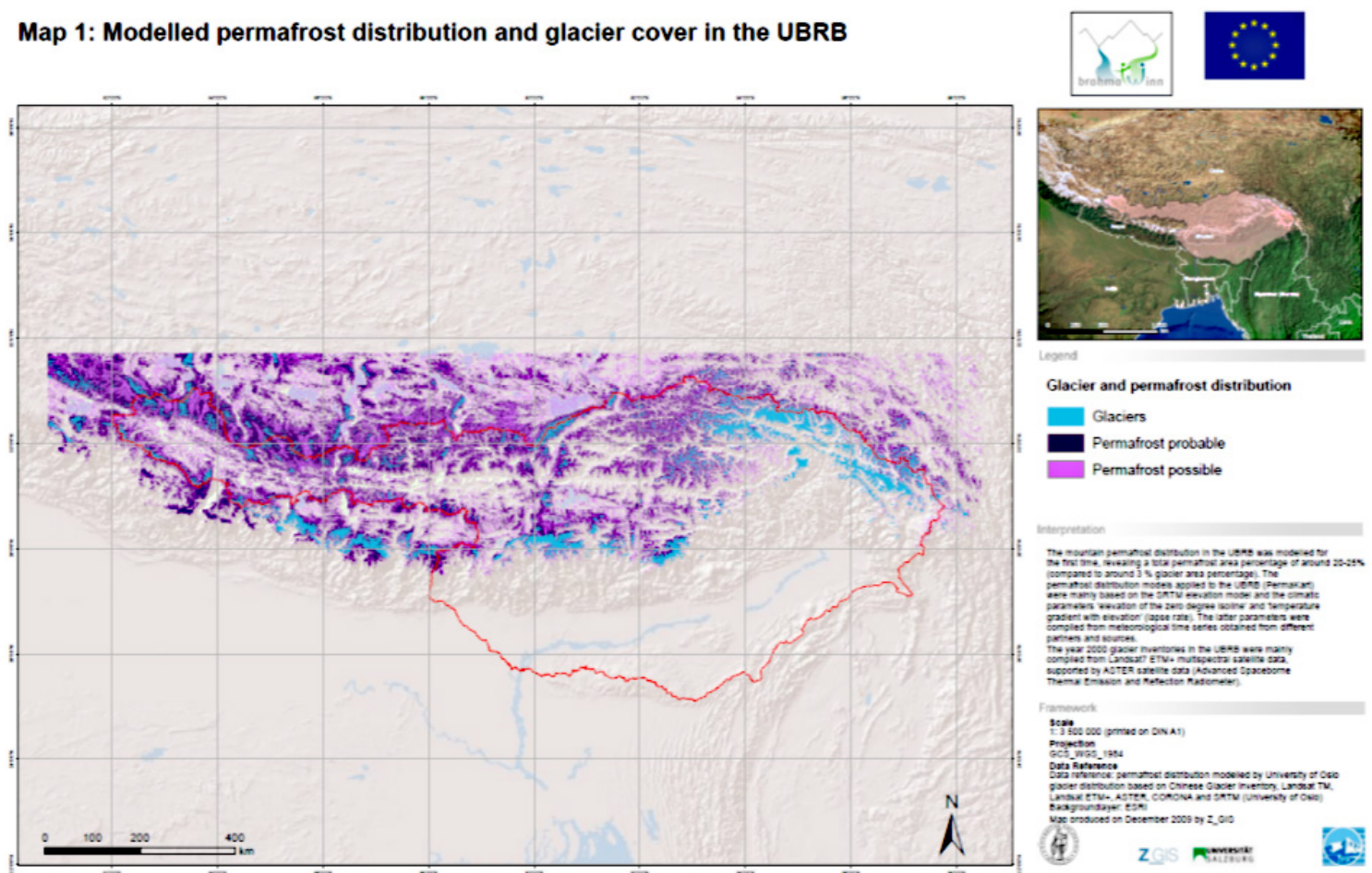

leoend

Glacier and permafrost distribution

Glaciers

- Permafrost probable

Permatrost possible
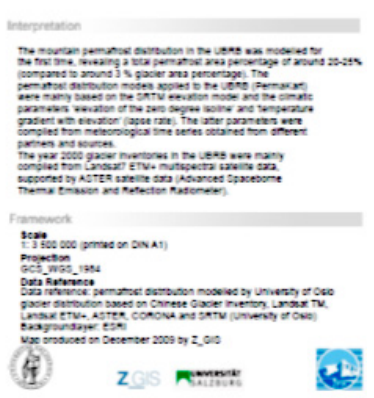

Figure 3. Glacier and permafrost distribution in the UBRB. 
Table 2. Area distribution of permafrost.

\begin{tabular}{lllll}
\hline & $\begin{array}{l}\text { Lhasa river } \\
\text { catchment }\end{array}$ & $\begin{array}{l}\text { Wang Chu } \\
\text { catchment }\end{array}$ & UBRB & $\begin{array}{l}\text { Salzach } \\
\text { UDRB }\end{array}$ \\
\hline Catchment area & $32752 \mathrm{~km}^{2}$ & $4687 \mathrm{~km}^{2}$ & $514720 \mathrm{~km}^{2}$ & $6688 \mathrm{~km}^{2}$ \\
\hline $\begin{array}{l}\text { Permafrost area } \\
\text { probable }\end{array}$ & $10026 \mathrm{~km}^{2}$ & $70 \mathrm{~km}^{2}$ & $76836 \mathrm{~km}^{2}$ & \\
$\begin{array}{l}\text { possible } \\
\text { total }\end{array}$ & $6000 \mathrm{~km}^{2}$ & $120 \mathrm{~km}^{2}$ & $49610 \mathrm{~km}^{2}$ & $279 \mathrm{~km}^{2}$ \\
total without glaciers (1970s) & $16026 \mathrm{~km}^{2}$ & $190 \mathrm{~km}^{2}$ & $126446 \mathrm{~km}^{2}$ & $279 \mathrm{~km}^{2}$ \\
\hline $\begin{array}{l}\text { Permafrost area percentage } \\
\text { total }\end{array}$ & $4991 \mathrm{~km}^{2}$ & $130 \mathrm{~km}^{2}$ & $108866 \mathrm{~km}^{2}$ & $184 \mathrm{~km}^{2}$ \\
total without glaciers & $47 \%$ & & & \\
\hline
\end{tabular}

The glacier hypsography shows that the maximum glacier areas are at around $5300 \mathrm{~m}$ a.s.l. for the entire UBRB, $5200 \mathrm{~m}$ for Wang Chu, $5700 \mathrm{~m}$ for Lhasa river and $2700 \mathrm{~m}$ for Salzach. The Lhasa river glacier cover at comparably high elevations might therefore be less vulnerable to a certain rise in air temperature than the other catchments. Compared to the entire UBRB, the Lhasa river glacier cover is restricted to a comparably small elevation band. The Wang Chu glacier cover shows a second peak at around $4500 \mathrm{~m}$ a.s.l. representing the large debris-mantled glacier tongues that survive at lower elevations due to their debris insulation. These lowelevation glacier parts are, though, particularly exposed to air temperature rise and could be stagnantly down-wasting. This process is known to potentially lead to the development of glacier lakes, a potential source of outburst floods.

Through empirical area-volume scaling and upscaling to the entire basin it was found that the glaciers in the UBRB lost about $20 \%$ of their volume between around 1970 and 2000. This totals to an ice volume loss of $175 \mathrm{~km}^{3}$, or $7 \mathrm{~km}^{3}$ per year, or a glacier mass balance of about $-0.3 \mathrm{~m}$ water equivalent per year, or about $0.015 \mathrm{~mm}$ sea level equivalent per year.

Permafrost distribution in the UBRB and the UDRB was modelled (Table 2, Figs. 2 and 3) and can be intersected with glaciers, glacier lakes, steep terrain etc. in order to identify potential interactions and climate change impacts (Fig. 4). Compared to the Lhasa river catchment (Xie et al., 2009) and the entire UBRB, the larger part of permafrost occurrence in the Wang Chu catchment is possible, not probable (Table 2). This indicates a larger area of permafrost close to the melting point and thus a higher sensitivity of the permafrost in the Wang Chu catchment to changes in boundary conditions most importantly air temperature and snow cover.

The permafrost area percentage in the UBRB is comparably high with $20-25 \%$, underlining the strong periglacial character of the basin (Table 2). For comparison, the glacier area percentage is significantly lower with around

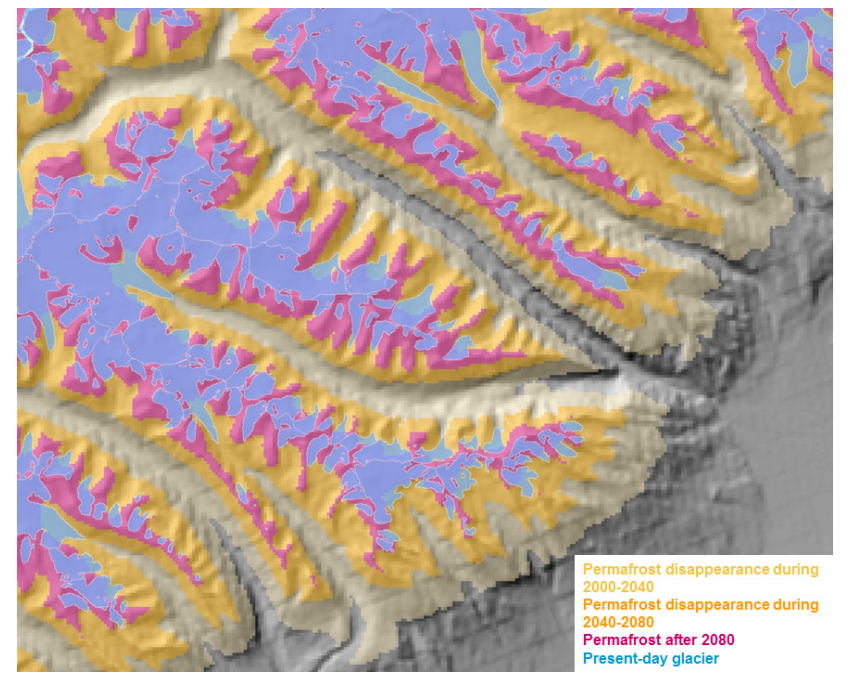

Figure 4. Detailed map of modelled increase of permafrost limit using IPCC scenario A1B, Lhasa river.

$3 \%$. Nearly half of the Lhasa river catchment is presumably underlain by permafrost, in contrast to $3-4 \%$ for the Wang Chu. Periglacial processes dominate in the Lhasa river catchment, whereas they play only a minor role in the Wang Chu catchment. As a consequence, changes in the ground thermal regime due to climatic changes will therefore have significantly more impact in the Lhasa river than in the Wang Chu catchment (Liu et al., 2010; You et al., 2007).

The largest permafrost areas in the UBRB and Lhasa river catchment are at around $5200 \mathrm{~m}$ a.s.l., and around $4900 \mathrm{~m}$ a.s.l. in the Wang Chu catchment. The permafrost area histograms reflect due to the strong elevationdependency of permafrost distribution mainly the topographic elevation distribution. The significantly lower elevation of permafrost areas in the Wang Chu catchment indicates a comparably large sensitivity to changes in air temperature 
Table 3. Classification scheme with subclasses for level 1 and level 2.

\begin{tabular}{|c|c|c|c|}
\hline \multicolumn{4}{|c|}{ BRAHMATWINN classification scheme } \\
\hline & Level 1 & & Level 2 \\
\hline No. & LULC & No. & LULC \\
\hline 10000 & Agriculture & $\begin{array}{l}1201 \\
1202 \\
1203\end{array}$ & $\begin{array}{l}\text { Arable land } \\
\text { Pasture and/or meadow } \\
\text { Plantation }\end{array}$ \\
\hline 20000 & Bare ground & $\begin{array}{l}2201 \\
2202\end{array}$ & $\begin{array}{l}\text { Soil } \\
\text { Rock and debris }\end{array}$ \\
\hline 30000 & Forest & $\begin{array}{l}3201 \\
3202 \\
3203 \\
3204 \\
3205\end{array}$ & $\begin{array}{l}\text { Coniferous } \\
\text { Decidious } \\
\text { Evergreen } \\
\text { Mixed } \\
\text { Plantation }\end{array}$ \\
\hline 40000 & Non forest vegetation & $\begin{array}{l}4201 \\
4202 \\
4203 \\
4204\end{array}$ & $\begin{array}{l}\text { Bushland } \\
\text { Alpine grassland } \\
\text { Grassland } \\
\text { Shrubland }\end{array}$ \\
\hline 50000 & Ice and snow & $\begin{array}{l}5201 \\
5202\end{array}$ & $\begin{array}{l}\text { Glacier } \\
\text { Snow }\end{array}$ \\
\hline 60000 & Built up areas & $\begin{array}{l}6201 \\
6202\end{array}$ & $\begin{array}{l}\text { Urban } \\
\text { Rural }\end{array}$ \\
\hline 70000 & Open water & $\begin{array}{l}7201 \\
7202\end{array}$ & $\begin{array}{l}\text { Water courses } \\
\text { Water bodies }\end{array}$ \\
\hline 80000 & Unclassified & $\begin{array}{l}8201 \\
8202\end{array}$ & $\begin{array}{l}\text { Clouds } \\
\text { Shadow }\end{array}$ \\
\hline
\end{tabular}

and snow cover. Though, these potential impacts affect only small areas due to the small permafrost area percentage in the Wang Chu.

In the Salzach basin, UDRB, the area percentage underlain by permafrost is in the order of 3-4\% (Table 2); perhaps even less, because the model applied to the UDRB allows slightly warmer conditions for the existence of permafrost compared to the UBRB permafrost model. Similar percentage numbers are found for the entire UDRB as for the Salzach.

\subsection{Land use and land cover}

For the LULC classification for the three Asian reference catchments Lhasa river (Tibet, China), Wang Chu (Bhutan), Brahmaputra near Guwahati (Assam, India), and the two European reference catchments Salzach (Austria/Germany) and Lech (Austria/Germany), suitable satellite data were acquired, selected and compiled. A joint LULC expert workshop was organized to work out a harmonized classification key (see Table 3) and thus to ascertain compatible classifications in Asia and EU. Level 1 and level 2 comprise 8 main classes and 22 subclasses, respectively. These classes can be derived from satellite imagery and additional, auxiliary data

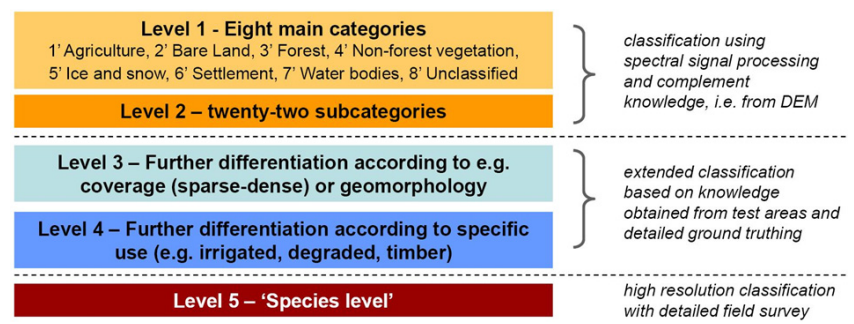

Figure 5. Overview of the BRAHMATWINN land use/land cover (LULC) classification scheme.

(like DTM derivatives). Level 3 and level 4 require additional external knowledge, either form experts or from field surveys. Level 3 contains structurally defined sub-classes (e.g. dense vs. sparse forest), whereas level 4 reflects specific land use types (e.g. irrigated vs. inundated). Level 5, finally, the "species level" requires very high spatial resolution data and field verifications, and thus can only be applied in selected fine-scaled test areas (Fig. 5).

During field missions to the reference catchments detailed ground truth information has been collected by taking a series of georeferenced (i.e. GPS tracked) photographs (Fig. 6). Additionally, the classifications in the UBRB catchment (especially those areas heavily influenced by shadow effects, mainly occurring in the Wang Chu catchment and the Lhasa catchment) have been improved by ground-truthing missions carried out by ICIMOD in October and November 2007. Verification has been based on a collection of 285 GPS measured ground reference points in Lhasa and 112 reference points in Bhutan, respectively. Due to cloud cover or other atmospheric effects (e.g. oblique sun angle due to winter season), as well as the constraints imposed by strong topographic effects, the LULC classification for 1990 was hampered. As an alternative for difficult conditions, the analysis was carried out using MODIS data sets, with a significant lower spatial resolution $(250 \mathrm{~m})$ as compared to Landsat $(30 \mathrm{~m})$, but with sufficient coverage.

In a test area within the Lhasa catchment the transition of specific classes has been studied between 1990 and 2000. Table 4 reveals major changes in this timeframe. Partly these changes may be attributed to the fact that satellite images from the year 2000 were captured in the winter season, where due to climatic reasons, e.g. regular grassland areas may have been interpreted as their marginalised form, i.e. alpine grassland.

Change analysis has also been carried out in the Guwahati floodplain test area based on a comparison between the Landsat ETM mosaic of 2000 and the Landsat TM mosaic of 1990. With a focus on bank erosion, the change of the river bed, along with increase or decrease of agricultural fields were investigated. In support to the evaluation of eco-hydrological relevant land-cover-types, highresolution satellite imagery was used for a fine-scale LULC classification. 

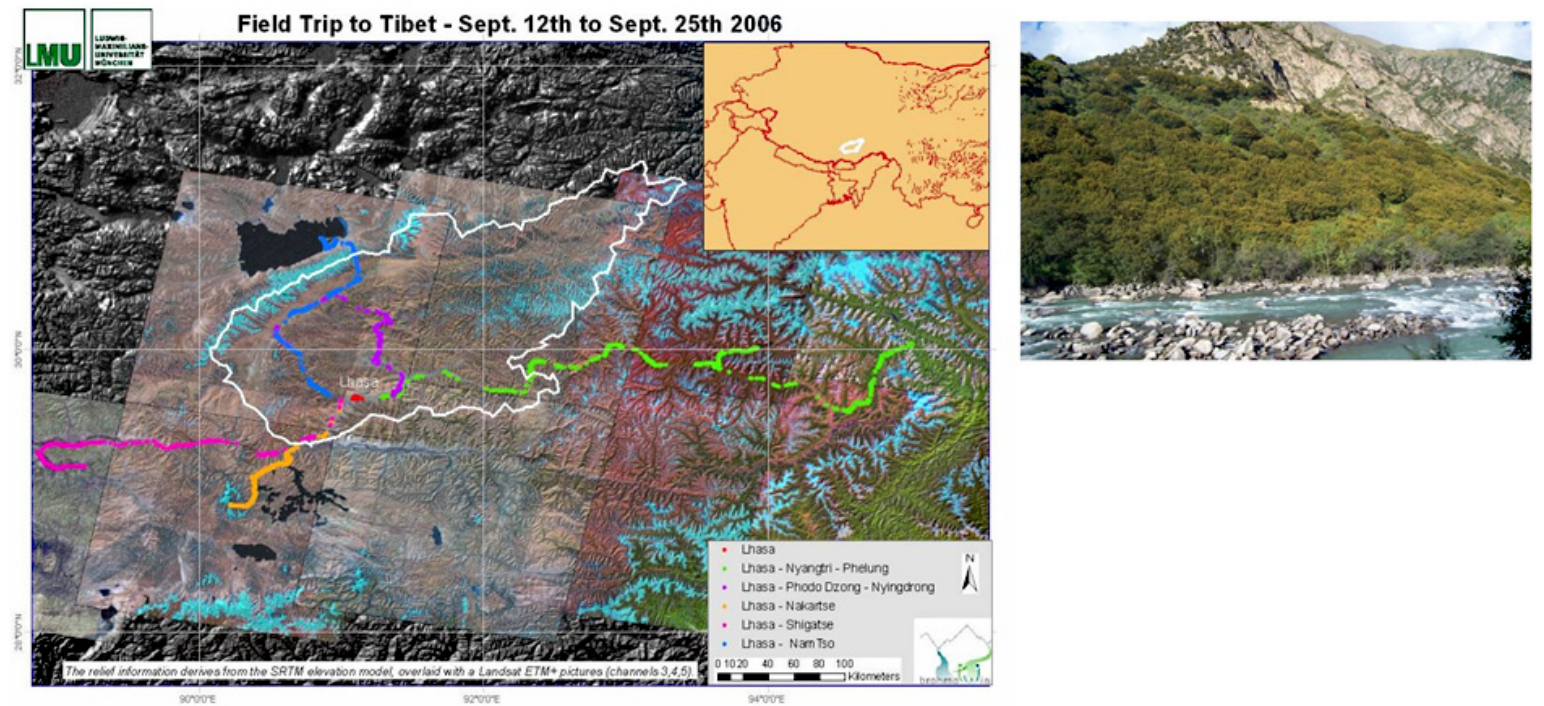

Figure 6. Left: GPS tracks for field trip around Lhasa catchment. Map compiled by M. Prasch, GPS tracklogs recorded by S. Lang. Right: Example of a georeferenced photograph. Holm oaks on the way from the Mi La Pass to Nyangtri (14.09.2006, M. Prasch).

Table 4. Changes of selected classes within a $6390 \mathrm{~km}^{2}$ sized subset of the Lhasa river catchment.

\begin{tabular}{lrrrrrr}
\hline Class & Area 1990 & Area 2000 & Same area & $(\%)$ & $\begin{array}{r}\text { Increase/ } \\
\text { decrease }\left(\mathrm{km}^{2}\right)\end{array}$ & $\%$ \\
\hline Alpine Grassland & 2111.04 & 3081.44 & 1627.24 & 77.08 & 970.40 & 45.97 \\
Arable land & 467.24 & 508.55 & 252.38 & 54.01 & 41.30 & 8.84 \\
Bushland/Shrubland & 1681.23 & 1068.40 & 501.85 & 29.85 & -612.83 & -36.45 \\
Bare Ground & 779.39 & 782.51 & 402.77 & 51.68 & 3.12 & 0.40 \\
Built up & 53.48 & 53.79 & 26.24 & 49.06 & 0.31 & 0.58 \\
\hline
\end{tabular}

Deriving land use/land cover information in the study areas using an expert classification system was successful (Figs. 7 and 8). The integration of Landsat satellite imagery with ancillary topographical and environmental data proved to be an effective technique. The developed expert system can also be used for image classification in areas with similar conditions. Although expert systems can improve the classification accuracy, there is still research needed for a fully automated classification.

\subsection{Groundwater vulnerability}

The general lack of data on all levels is the most limiting factor of the entire groundwater investigation. The use of the DRASTIC model method to assess aquifer vulnerability is a choice facing this problem as the input data can be derived or estimated from freely available geographical data. However the vulnerability assessment should be most likely considered as an overview tool, because of the lack of data and its quality. The origin and reliability of the input data can differ among individual categories.

\subsubsection{Depth of groundwater}

Based on data provided by the Indian Institute of Technology the depth of groundwater was interpolated using natural neighbourhood procedure for 52 reference objects measured once or several times during years 2000-2006 (there were 10 more points available without spatial referencing). Unfortunately there are only shallow dug wells on file, no data of deeper aquifer exploration. Furthermore, the distribution of observed wells is neither regular in position nor in periodicity. An assumption was taken with respect to the slope in ground water keeps the similar trends in Brahmaputra valley itself and generally coherent with terrain slope and elevation. At higher elevations no groundwater level is assumed.

\subsubsection{Net precipitation}

As there was no information provided on evaporation and surface runoff measurements available, the recharge values have been derived from public data on precipitation in India provided by Assam Company of America (2010) and 
Map 5: UBRB reference catchment: Wang Chu

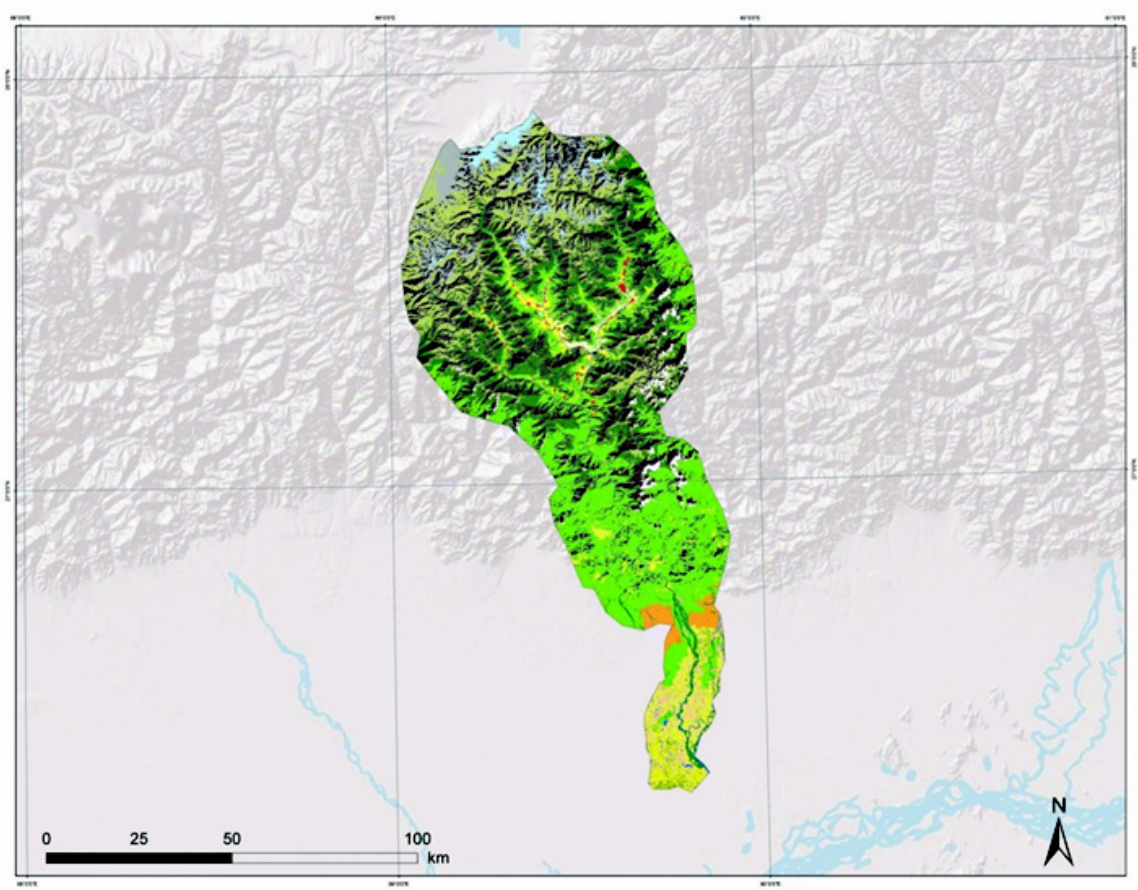

Figure 7. Land use/land cover classification for the Wang Chu river basin (Bhutan).

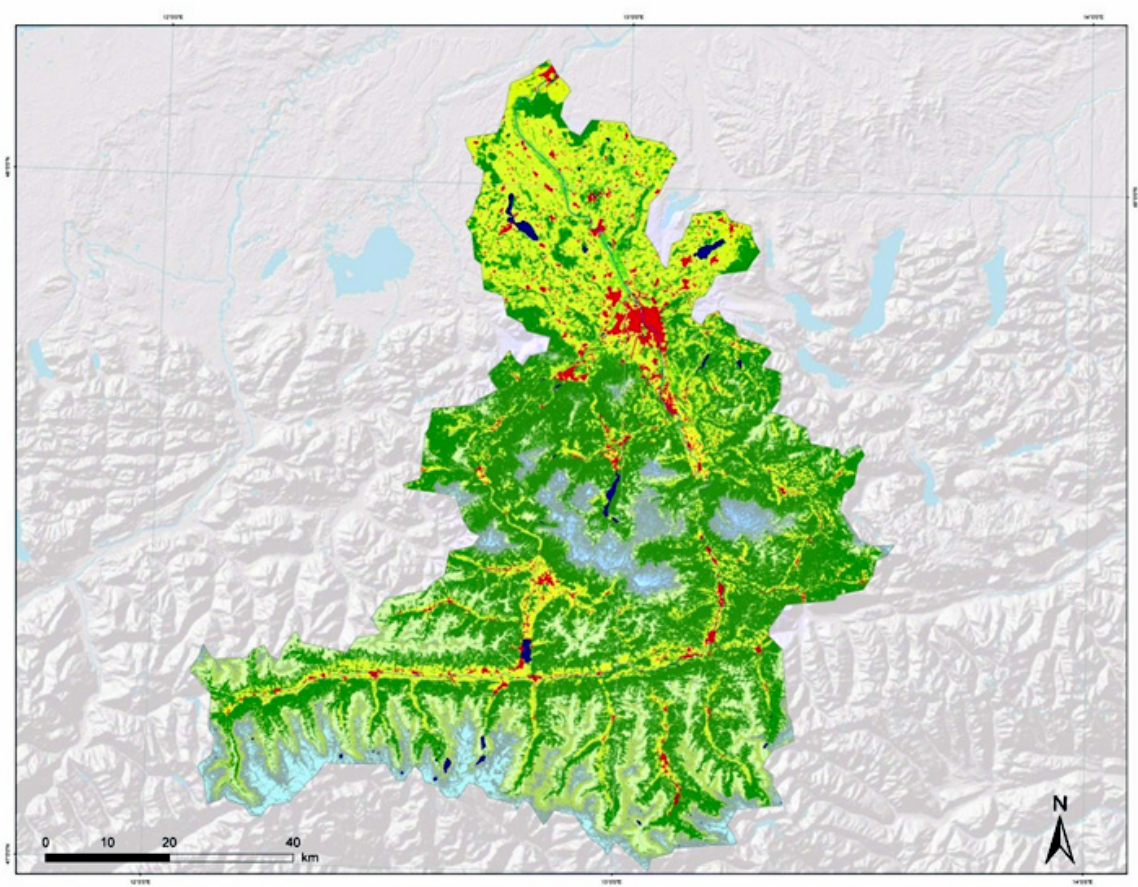

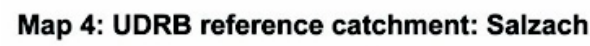

Map 4: UDRB reference catchment: Salzach

Figure 8. Land use/land cover classification for the Salzach river basin (Austria/Germany).
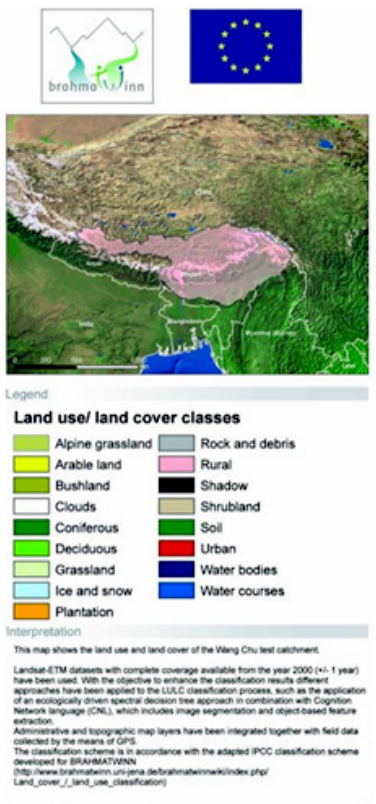

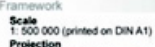

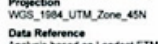

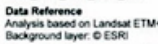

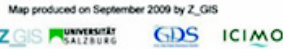
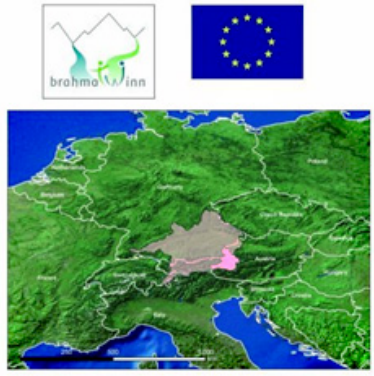

Land use/ land cover classes

$\square$ Grasland $\square$ Background

$\square$ Arable land $\square$ Deciduous

Bare Ground $\square$ Alpine Graslan

ice and Snow Waterbodies

Conferous Watercources
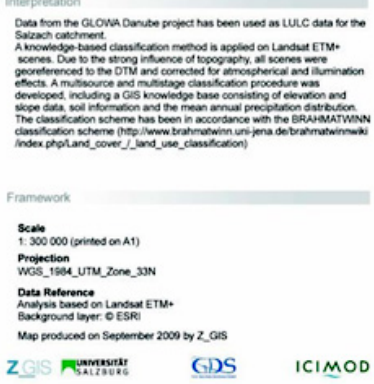

$I C I M O D$ 
Table 5. Combined parameters and weights for DRASTIC modelling.

\begin{tabular}{|c|c|c|c|c|c|c|c|c|c|c|c|c|c|}
\hline \multicolumn{2}{|c|}{$\begin{array}{l}\text { Depth to } \\
\text { groundwater }\end{array}$} & \multicolumn{2}{|c|}{ Recharge } & \multicolumn{2}{|l|}{$\begin{array}{l}\text { Aquifer } \\
\text { media }\end{array}$} & \multicolumn{2}{|c|}{$\begin{array}{c}\text { Soil } \\
\text { properties }\end{array}$} & \multicolumn{2}{|c|}{$\begin{array}{l}\text { Terrain } \\
\text { slope }\end{array}$} & \multicolumn{2}{|c|}{$\begin{array}{c}\text { Impact of } \\
\text { vadose zone }\end{array}$} & \multicolumn{2}{|l|}{ Conductivity } \\
\hline$[\mathrm{m}]$ & rate & {$\left[\mathrm{mm} \mathrm{y}^{-1}\right]$} & rate & [category] & rate & [category] & rate & {$[\%]$} & rate & [category] & rate & {$\left[\mathrm{m} \mathrm{s}^{-1}\right]$} & rate \\
\hline $0-5$ & 10 & $5-104$ & 1 & weath. metamorphic & 3 & clay & 1 & $0-2$ & 10 & silt/clay & 1 & $4.17 \mathrm{E}-09-4.17 \mathrm{E}-07$ & 1 \\
\hline \multirow[t]{6}{*}{$5-10$} & 9 & 104-161 & 3 & metamorphic & 8 & clayey silt & 3 & $2-6$ & 9 & shale & 3 & $4.17 \mathrm{E}-07-1.25 \mathrm{E}-06$ & 2 \\
\hline & & $161-278$ & 6 & metamorphic/igneous & 4 & silt & 4 & $6-12$ & 5 & limestone & 6 & $1.25 \mathrm{E}-06-2.92 \mathrm{E}-06$ & 4 \\
\hline & & $278-398$ & 8 & sedimentary & 8 & fine sand & 6 & $12-18$ & 3 & sandstone & 6 & $2.92 \mathrm{E}-06-4.17 \mathrm{E}-06$ & 6 \\
\hline & & $396-1350$ & 9 & & & medium sand & 8 & $>18$ & 1 & sand/gravel & 8 & $4.17 \mathrm{E}-06-8.34 \mathrm{E}-06$ & 8 \\
\hline & & & & & & coarse sand & 9 & & & basalt & 9 & $>8.34 \mathrm{E}-06$ & 10 \\
\hline & & & & & & gravel & 10 & & & limestone & 10 & & \\
\hline
\end{tabular}

a recent study on groundwater resources of India (Chatterjee and Purohit, 2009). The precipitation data were interpolated using natural neighbourhood approach to provide zones comparable with recharge zones by Chatterjee and Purohit (2009). Based on these data sources there were modified recharge zones determined to be compared with groundwater draft zones (Chatterjee and Purohit, 2009) and to provide source data for both DRASTIC and groundwater availability investigation.

\subsubsection{Aquifer and soil media}

According to a study on groundwater resources of India (Chatterjee and Purohit, 2009) there were 4 prevailing groups of aquifers determined: (1) Alluvium: Describes the quaternary sediments surrounding the Brahmaputra river basin, highest permeability of all the present aquifers; (2) Extensive alluvium: Tertiary and quaternary sediments in the main area of Assam, stretching from Shillong Plateau eastwards to Jorhat and southwards to Cachar; (3) Crystalline rocks: Proterozoic massifs in the region of North Cachar Hills, Igneous and Metamorphic rocks; (4) Aquifer in hilly areas: Consists of Igneous and Metamorphic rocks in the districts of Lakhimpur, Dhemaji, Dibrugarh and Sonitpur.

All the three DRASTIC categories concerning soil properties derived from Assam soil map (Sehgal et al., 1987). There are soil groups mapped and referenced to describe prevailing texture categories. The soil classification is based on USDA system. The only used value is the DRASTIC rating itself. The analyses are based on relative texture classification, related to texture categories.

Compiled data are converted to DRASTIC rated layers and all the parameters consequently combined (see Table 5). The interpretation is based on DRASTIC INDEX (DI) weighting formula and corresponding indicators of aquifer vulnerability are determined by weighted sum. The output coverage contains graphical representation based on raster data analysis corresponding to DI values (see Fig. 9). The output features have the attribute from the original feature from the input coverage and the feature in the intersect coverage, which they intersect. The values for the final index's, i.e. "Low,"
Table 6. DRASTIC index values.

\begin{tabular}{lclc}
\hline parameter & weight & vulnerability & $\begin{array}{c}\text { DRASTIC } \\
\text { index values }\end{array}$ \\
\hline depth to groundwater & 5 & very low & $87-217$ \\
net precipitation & 4 & Low & $217-348$ \\
aquifer media & 3 & moderate & $348-478$ \\
soil media & 2 & High & $478-609$ \\
terrain slope & 1 & very high & $609-740$ \\
\hline
\end{tabular}

"Medium," etc., were created by first applying the Jenk's Natural Breaks classification for all regions into five classes, then taking the average for each class and applying the same values to all regions to be consistent across the entire region. The used rating is therefore applicable for the situation of Assam only as the classes were set on relative range of DI values (Table 6).

\subsection{Eco-hydrology and wetland characteristics}

The Assam part of the Brahmaputra catchment is characterized by three terrestrial eco-regions within the Tropical and Subtropical Moist Broadleaf Forests biome, of which the Brahmaputra Valley semi evergreen forest eco-region has the highest proportion within the river corridor. The river-scape in the Assam river valley provides low ecosystem services in contrast to the slopes and hills, due to the fact that lower elevations showed higher proportions of arable land and built up areas. These LULC-classes are the main driving forces for pollution. Natural environment and ecosystem services information are relevant for the further processing by the social science groups, providing indicators to be linked with socio-economic models.

Local scale and River Basin scale were combined by a rule-based expert system at sub-catchment scale, which uses the LULC classification and the NDVI as basis to identify alluvial areas, lakes, alpine swamps and meadows, floodplains and beels - typical lake-like water bodies of different size in close connection with the river, in Assam and Bhutan. These different wetland classes were further differentiated 
Table 7. Hydrological classes based on the hydrological dynamics of the different wetlands (Keddy, 2000).

\begin{tabular}{lll}
\hline Hydrological class & Description & Wetland class \\
\hline Flooding & $\begin{array}{l}\text { wetlands depending mainly on flooding and inundation } \\
\text { with sediment rich runoff from the river }\end{array}$ & alluvials, floodplains, beels \\
\hline Groundwater & $\begin{array}{l}\text { wetlands depending on groundwater dynamics with } \\
\text { seasonal rise and falling of groundwater }\end{array}$ & lakes, swamps \\
\hline Hybrid & $\begin{array}{l}\text { wetlands of a hybrid nature comprising flooding and } \\
\text { groundwater }\end{array}$ & beels, lakes \\
\hline Slope & $\begin{array}{l}\text { wetlands at footslopes fed by interflow from the } \\
\text { adjacent slopes }\end{array}$ & swamps, meadows \\
\hline
\end{tabular}

$\aleph_{N}$

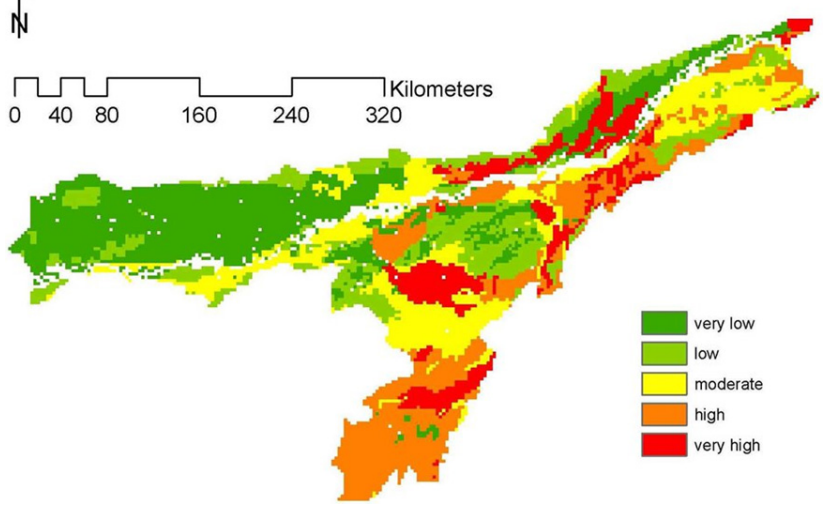

Figure 9. Assam - aquifer vulnerability based on DRASTIC INDEX value.

into four hydrological classes by their hydrological dynamics (Table 7).

In the Synthesis Report Wetland and Water (Millennium Ecosystem Assessment, 2005) the relative magnitude [low $(\cdot)$ - medium $(\bullet)$ - high $(\bullet)$ ] of wetland-based ecosystem services is based on expert opinion, and provides a general pattern for wetland classification in a global scale. This framework was adapted for the wetland classes found in the BRAHMATWINN twinning basins at sub-catchment scale. The assessment was conducted using the information from local data which was collected during field trips in the respective Sub-catchments in Tibet, Assam and Bhutan, and through the evaluation of wetland databases (Ramsar Site Information Service, Global Wetland Inventory Database, Wetlands of India and European Environmental Agency). The median of the values of the following ecosystem services was used to assess the biodiversity of the wetlands which are refugia, biological control, pollination and genetic/medicinal resources.

Vulnerability of the wetlands was assessed particularly with regard to (I) the pressure of the adjacent human population on wetlands and to (II) the possible effects of climate
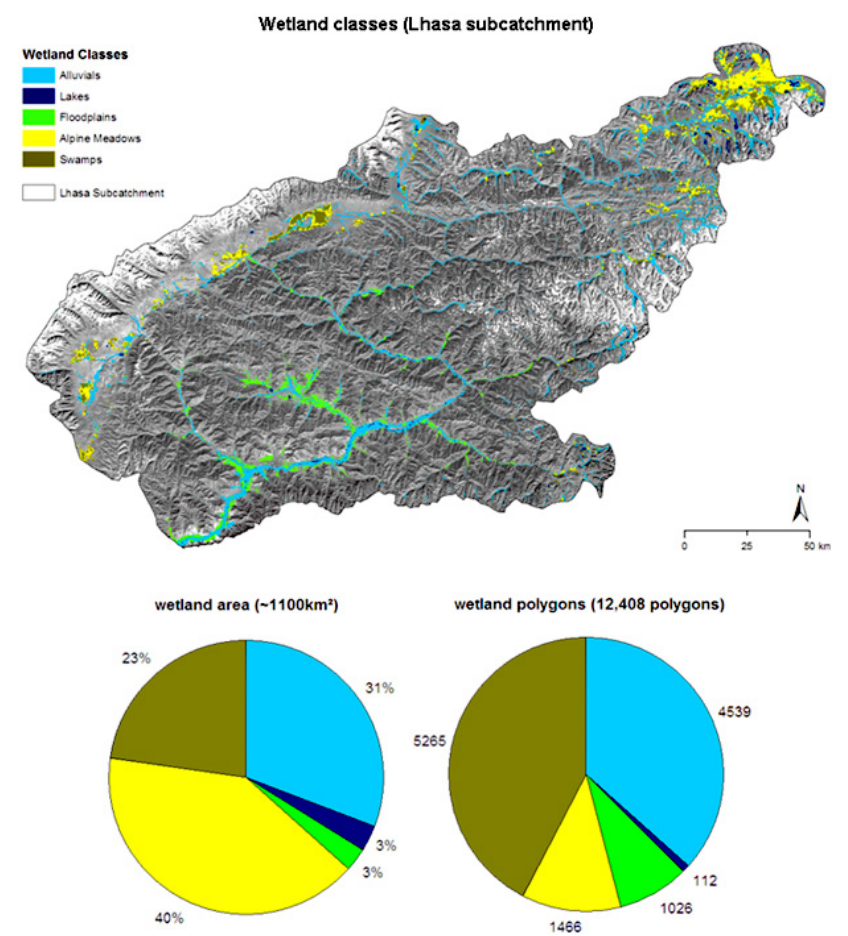

Figure 10. Lhasa sub-catchment: Wetland classes (top); Wetland area (left) and polygons (right).

change on the wetland distribution. Threat caused by density of settlements was partly derived from population-data provided by project partners working on socio-economic aspects.

In the sub-basins of the twinning rivers characteristic locations with a potential of supporting wetlands were assessed on the basis of different sources: information available to the public as well as provided by project partners, using a geo-statistical approach based on expert opinion, hydrological data and inclination information derived from digital elevation information. Hydrological information was also used to determine vulnerability of wetlands on a general level (Fig. 10). 
Table 8. Lhasa Sub-catchment: Ecosystem Services, Biodiversity and Vulnerability Assessment: Relative magnitude [low (•) - medium $(\bullet)$ - high (๑)]. Weighting follows Millenium Ecosystem Assessment (2005).

\begin{tabular}{|c|c|c|c|c|c|c|c|c|c|c|c|}
\hline Ecosystem Services & 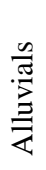 & 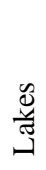 & $\begin{array}{l}\text { 志 } \\
\frac{\pi}{0} \\
\frac{0}{0} \\
\frac{0}{I}\end{array}$ & 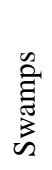 & 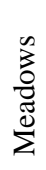 & & 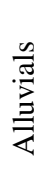 & 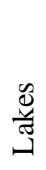 & $\begin{array}{l}\stackrel{0}{\Xi} \\
\frac{\pi}{2} \\
\frac{0}{8} \\
\frac{0}{I}\end{array}$ & 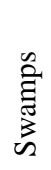 & 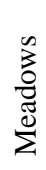 \\
\hline Provisioning & & & & & & Biodiversity & $\bullet$ & • & • & . & . \\
\hline Food, Raw materials & $\bullet$ & 0 & 0 & $\bullet$ & $\bullet$ & & & & & & \\
\hline Genetic, medicinal resources & . & . & . & & & overall median & $\bullet$ & 0 & ○ & . & . \\
\hline Fresh water & ○ & 0 & . & . & . & $\operatorname{var}( \pm 1)$ & 1 & 1 & 1 & 0 & 0 \\
\hline Regulating & & & & & & Vulnerability & & & & & \\
\hline Climate regulation & . & 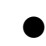 & 0 & 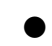 & $\bullet$ & Human Dimension & . & $\bullet$ & 0 & . & . \\
\hline Water regulation & 0 & . & 0 & & & Climate Change & . & $\bullet$ & 0 & 0 & 0 \\
\hline Water supply & $\bullet$ & ○ & 0 & . & & & & & & & \\
\hline Waste treatment & 0 & $\bullet$ & 0 & $\bullet$ & . & & & & & & \\
\hline Erosion control and sediment retention & $\bullet$ & . & $\bullet$ & . & . & & & & & & \\
\hline Disturbance regulation & $\bullet$ & $\bullet$ & $\bullet$ & . & . & & & & & & \\
\hline \multicolumn{12}{|l|}{ Supporting } \\
\hline Refugia & $\bullet$ & 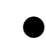 & 0 & • & • & & & & & & \\
\hline Biological control & 0 & 0 & 0 & . & . & & & & & & \\
\hline Pollination & . & . & . & . & . & & & & & & \\
\hline Soil formation & $\bullet$ & & $\bullet$ & . & . & & & & & & \\
\hline nutrient cycling & $\bullet$ & 0 & 0 & . & & & & & & & \\
\hline
\end{tabular}

\subsubsection{Upper Brahmaputra River Basin, Lhasa sub-catchment}

The overall relative value of the wetlands in the Lhasa subcatchment were assessed from low to high magnitude (see Table 8). In addition to rivers and their plains (alluvials), floodplains provide important regulation and supporting services. As azonal ecosystems, they are characterized by a rich biodiversity, but are highly endangered by human activities and climatic changes. Climatic changes will have the highest effect on alpine swamps and meadows, even their species composition is not completely known until now (according to Bernhard Dickoré participating in the Flora Tibetica).

\subsubsection{Upper Brahmaputra River Basin, Assam sub-catchment}

The large wetland areas in the Brahmaputra Valley provide important provisioning, regulation and supporting services and a rich biodiversity - the overall relative magnitude was evaluated from high to medium value. Most of the wetlands in the valley have been highly influenced by human activities since centuries. Rivers and their alluvial plains and the countless small oxbows, swamps and other waterlogged areas (beels) supply important resources for the local people.
However, like the semi-natural/natural floodplains, they are highly vulnerable to increasing human activities and climatic changes.

\subsubsection{Upper Brahmaputra River Basin, Wang Chu sub-catchment}

The mountainous regions in Bhutan cover only small wetland patches, which were evaluated high and low relative magnitude. Rivers and their plains (alluvial) and the small floodplain remnants provide important provisioning, regulating and supporting services. The diversity of the mountainous regions is huge, but mainly unexplored (especially some glacial lakes in the northern part of the sub-catchment). The numerous beels in the lower part are highly endangered like in Assam.

\subsubsection{Upper Danube River Basin, Salzach and Lech sub-catchments}

The wetlands in the Salzach and Lech sub-catchments in the UDRB were evaluated from low to high relative magnitude. The azonal ecosystems are biodiversity hotspots. The floodplains provide, like in Asia, important regulating and supporting services. But most of the wetlands are highly altered 


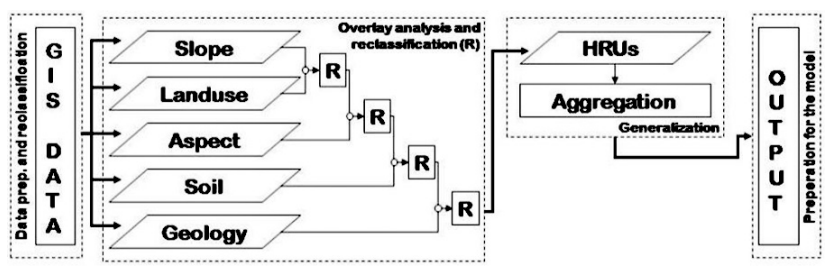

Figure 11. Schema to delineate HRUs.

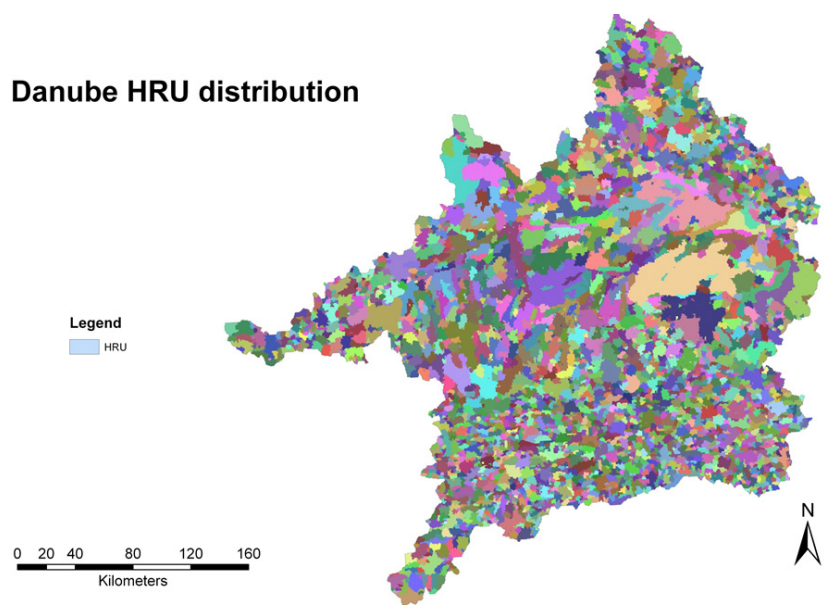

Figure 12. HRUs delineation for the UDRB.

by human activities and therefore reduced in their value and function. As a regulatory, strategies like the Natura 2000 network or the EU Water Framework Directive should have positive effects on the endangered situation of the wetlands.

\subsection{Delineation of Hydrological Response Units (HRU)}

As described by Flügel (1995, 1997) HRU are delineated based on detailed hydrological system analyses in a Geographical Information System (GIS) by applying a stepwise procedure (Fig. 11). In a first step the elevation data have to be corrected and the morphological information is derived from the DEM. Then data are classified knowledge based into hydrological important classes and the nominal scaled datasets are reclassified into classes with hydrological relevance. The reclassified datasets were combined in a GIS by means of overlay functions. Finally a set of many different small areas emerges. These areas have similar characteristics within their border, but they are different to their neighbour areas. After the final step of eliminating the smallest polygons and joining the attributes, the final HRUs are delineated (Fig. 12, Table 9).

The knowledge based HRU delineation relies on intensive data pre-processing and the harmonization of data sets. Whereas the entire process chain is partly automated (by using for example data processing routines implemented in ArcGIS), there is still manual interaction required. Due to
Table 9. Number of HRUs delineated and the number of classes produced in all reference catchments.

\begin{tabular}{lcc}
\hline Reference catchment & \# of HRUs & \# of classes \\
\hline Salzach & 6728 & 93 \\
Lech & 2326 & 68 \\
Lhasa & 8734 & 39 \\
Wang Chu & 23887 & n/a \\
Assam & 372822 & n/a \\
\hline
\end{tabular}

the different characters of the reference catchments (topography, land use, land cover, soil, etc.) and the various data sources used (e.g. soil data available in different schemes) the average size of the HRUs in the five reference catchments varies.

\section{Contributions to sustainable IWRM}

The innovative IWRM challenge posed to BRAHMATWINN was to elaborate in the macro-scale twinning basins the spatial distributed modelling and evaluation of adaptive IWRM options for mitigating likely impacts from climate change on the hydrological regimes. This challenge required a thorough river basin systems analysis as a prerequisite to identify and classify systems similarities that indicate common dynamics in the twinning UDRB and UBRB. BRAHMATWINN provided the basis for management and technological tools by assessing both natural environment and human dimension, e.g. the water cycle, water quality and availability, water allocation and sanitation, water related issues of gender, poverty and others by integrated indicators identified for the UDRB and UBRB to monitor the respective system status.

Glacier cover and permafrost distribution are in parts significantly different between the river basins and test catchments investigated. The UBRB has a strong periglacial character rather than a glacial one. In the UDRB, both the glacial and periglacial zones occupy comparably small areas. In the year 2000, the Lhasa river and Wang Chu catchments in the UBRB and the Salzach catchment in the UDRB had an glacier area percentage in the order of $1.1 \%$ to $1.6 \%$, the entire UBRB an percentage of around 3\%. The relative glacier area shrank since the 1970 s by around $0.2 \%$ due to a glacier area loss of around $6-7 \%$ per decade. The glacier volume loss corresponding to the above glacier area loss, i.e. the loss of water reserve bound in glaciers, must have been in the order of $20 \%$ since the 1970 s for the entire UBRB. The mountain permafrost distribution in the UBRB was modelled for the first time, revealing a total permafrost area percentage of around $20-25 \%$ (compared to around $3 \%$ glacier area percentage). In contrast, the permafrost area in the UDRB is in the order of $3-4 \%$ in maximum. 
Aquifer vulnerability assessment created by a standardized procedure is a valuable and particularly easy to use tool that can be applied on all stages of decision making. Aquifer vulnerability should be considered in case of any activity or construction with a potential impact on groundwater. The scale ranges from agricultural measures (impacts of irrigation crops, tillage, fertilizers, pesticides, etc.) over civil engineering projects (both hydraulic and non-hydraulic structures) to land use planning. Especially in the large scale assessments the aquifer vulnerability represents essential information regarding groundwater discharge, infiltration, and risk of contamination. Also the response of aquifers needs to be taken into account in case of backwater creation formed by hydraulic engineering projects. The resulting map layers provide an applicable indicator for situations where more extensive investigation should be performed.

When trying to (i) locate more precisely the borders of wetlands and their seasonal variation, (ii) describe wetland vulnerability with respect to the water sources supporting the individual wetland types, (iii) select and identify the wetland ecotones and their associated ecosystem services, (iv) determine the importance of individual wetlands for sustaining a reasonable level of livelihood qualities for the surrounding population as well as its impact on different wetland types and locations, and (v) focus on the possible changes in wetland status due to climate change effects, we learnt in the light of IWRM. As a first prerequisite for good results, more detailed information is needed on the local water regime of wetlands in several regions of the three test regions - and, of course, in the whole UBRB. This set of information must be supplemented by a sufficiently dense net of recording stations in the rivers' floodplains, to accurately understand the wetland reaction to hydrological and climate change-induced changes and to facilitate object-oriented actions. Additionally, in floodplains - among the most important wetland types in the UBRB, even in higher altitudes - much more detailed elevation models are needed to fully describe seasonal and inter-annual effects of river floods and groundwater flow, as the main water sources of this type of wetlands. Subtle elevation differences determine the existence, development or deterioration of ecotones, a major source of biological diversity and ecosystem services, as well as transitional zones of enhanced environmental vulnerability and a focus of population pressure.

\section{Conclusions and recommendations}

The water resources bound in glacier-ice have in the UBRB as well as in the UDRB decreased significantly in the recent decades. This trend will according to most climate scenarios continue. However, the actual down-stream impact of these changes to the run-off regime depends much on the distance to the glaciers. The small glacier area percentage of a few percent indicates that the glacier-impact on river run-off in the lower part of the river basins studied will be small. This is in contrast to perceptions found in media and parts of the public, that the lowlands around the Himalayas will be heavily affected by river run-off changes due to glacier shrinkage. Such effects, however, increase towards the headwaters with glacier cover. The areas underlain by permafrost in the UBRB are significantly larger than the glacierized areas. The impacts of permafrost changes on the river-runoff are still hardly understood, but could in cases such as the UBRB have potentially large impacts. Glacier maps have been obtained from repeated air- and space borne imagery. The methods used are very robust and well-established. This study confirmed these earlier findings and proofs that the methods can in deed be used for operational glacier mapping and monitoring. However, glaciological expertise is absolutely necessary to manually identify and check individual glaciers. The permafrost modelling tools used are equally known as being robust for regional scales. Model performance, though, strongly depends on sufficiently distributed and accurate meteorological data over several years, preferably decades. This requirement is in some areas difficult to fulfil properly.

In general the region of Assam is characterized by high aquifer vulnerability. The main reason is the presence of very shallow aquifers all over the area, where the typical depth to groundwater makes approximately up to $5 \mathrm{~m}$. In some regions the depths reach 10 meters, but just very rarely there is significantly deeper aquifer under exploitation. Highest aquifer vulnerability has been determined in the districts of Nagaon, Karbi Anglong and in lower elevated parts of Sonitpur and Lakhimpur. The highest safety (lowest aquifer vulnerability) was detected in the mountain districts of Kokrajhar, Bongaigaon, Nalbari, Barpeta and higher parts of Karbi Anglong.

The importance of wetlands as a source of livelihood services and quality is often not appreciated well enough by the local population to be allocated a high priority in their objectives for regional development. When conflicts arise due to limitations in anthropogenic landuse types and strategies in rural planning, the reasonable control of population growth and increase in ecological footprint is usually the very last strategy to consider, as compared to technical solutions or/and the enhanced sacrifice of ecotonal landscape elements and wetland areas. The aim lies in the actual, real-world integration of all relevant policy levels, decision making parties and stakeholders, necessary external/internal mediation processes, and all relevant scientific and economic expertise needed to conserve and sustain wetlands and their services throughout the UBRB, presently densely and less densely populated areas alike, despite the considerable difficulties to be expected. 
Acknowledgements. Work has been carried out with substantial financial support from the FP-6 project BRAHMATWINN, contract number GOCE-036952.

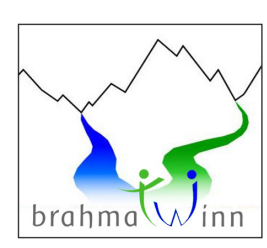

The interdisciplinary BRAHMATWINN EC-project carried out between 2006-2009 by European and Asian research teams in the UDRB and in the UBRB enhanced capacities and supported the implementation of sustainable Integrated Land and Water Resources Management (ILWRM).

\section{References}

Aller, L., Bennett, T., Lehr, J. H., and Petty, R. J.: DRASTIC - a standardized system for evaluating ground water pollution potential using hydrogeologic settings, US Environmental Protection Agency, Robert S. Kerr Environmental Research Laboratory, Office of Research and Development, EPA/600/2-85/018, 163 pp., 1985.

Assam Company of America: Assam Portal, http://www.assam.org/ content/temperatures-and-rainfall, last access: March 2010.

Chatterjee, R. and Purohit, R. R.: Estimation of replenishable groundwater resources of India and their status of utilization, Curr. Sci. India, 96, 12, 1581-1591, 2009.

Das, P. J.: The problem of fluorosis in south-central Brahmaputra valley in Assam, Water, Climate and Hazard Programme, AARANYAK, India, internal report, 2009.

Flügel, W.-A.: Delineating Hydrological Response Units (HRU's) by GIS analysis for regional hydrological modelling using PRMS/MMS in the drainage basin of the River Bröl, Germany, Hydrol. Process., 9, 423-436, 1995.

Flügel, W.-A.: Combining GIS with regional hydrological modelling using Hydrological Response Units (HRUs) - An application from Germany, Math. Comput. Simulat., 43, 305-312, 1997.

Flügel, W.-A.: Applied Geoinformatics for sustainable IWRM and climate change impact analysis, Technology, Resource Management \& Development, 6, 57-85, 2009.

Frauenfelder, R. and Kääb, A.: Glacier mapping from multitemporal optical remote sensing data within the Brahmaputra river basin, Conference proceedings: Remote Sensing of the Environment 2009, Stresa, Italy, abstract number 299, 2009.

Hoelzle, M.: Mapping and modelling of mountain permafrost distribution in the Alps, Norwegian Journal of Geography, 50, 11-15, 1996.
Jha, M. K. and Sebastian, J.: Vulnerability Study Of Pollution Upon Shallow Groundwater Using Drastic/GIS, Map India 2005, Geomatics, 2005.

Kääb, A., Paul, F., Maisch, M., Hoelzle, M., and Haeberli, W.: The new remote sensing derived Swiss glacier inventory: II. First results, Ann. Glaciol., 34, 362-366, 2002.

Kabera, T. and Zhaohui, L.: A GIS based DRASTIC Model for Assessing Groundwater in Shallow Groundwater Aquifer in Yuncheon Basin, Shanxi, China, Research Journal of Applied Sciences, 3(3), 195-205, 2008.

Keddy, P. A.: Wetland Ecology: Principles and Conservation, Cambridge University Press, UK, 2000.

Krause, P.: Quantifying the impact of land use changes on the water balance of large catchments using the J2000 model, Phys. Chem. Earth, 27, 663-673, 2002.

Lambrecht, A. and Kuhn, M.: Glacier changes in the Austrian Alps during the last three decades, derived from the new Austrian glacier inventory, Ann. Glaciol., 46, 177-184, 2007.

Leavesley, G. H., Lichty, R. W, Troutman, B. M., and Saindon, L. G.: Precipitation-runoff modeling system-User's manual, US Geological Survey Water-Resources Investigations Report 834238, 207 pp., 1983.

Liu, J., Kang, S., Gong, T., and Lu, A.: Growth of a high-elevation large inland lake, associated with climate change and permafrost degradation in Tibet, Hydrol. Earth Syst. Sci., 14, 481-489, doi:10.5194/hess-14-481-2010, 2010.

Millennium Ecosystem Assessment: Ecosystems and Human Wellbeing: Wetlands and Water Sythesis, World Resources Institute, Washington DC, 2005.

Paul, F., Kääb, A., Maisch, M., Kellenberger, T., and Haeberli, W.: The new remote-sensing-derived Swiss glacier inventory: I. Methods, Ann. Glaciol., 34, 355-361, 2002.

Seghal, J., Saxena, R. K., and Vadivelu, S.: The soil map of Assam, Field manual, soil resource mapping of different states in India, National Bureau of Soil Survey and Land Use Planning (NBSS), 37 pp., 1987.

Xie, J., Liu, J., Du, M., Kang, S., and Wang, K.: Analysis of the observation results of temperature and precipitation over an alpine mountain, the Lhasa River Basin, Adv. Earth Sci., 28(3), 223230, 2009.

You, Q., Kang, S., Tian, K., Liu, J., Li, C., and Zhang, Q.: Preliminary Analysis on Climatic Features at Mt. Nya-inqentanglha, the Tibetan Plateau, J. Mt. Sci., 25(4), 497-504, 2007. 